\title{
Obituaries
}

\section{CHARLES HOLWELL TALBOT}

(1906-1993)

Charles H. Talbot, PhD, BD, BCL, died at his home in London on 13 September 1993 of a stroke at the age of eighty-seven. He was best known to medical history as a leading expert on medieval England. He also made notable contributions to the fields of Cistercian studies and the history of the Anglo-Saxon church.

Born in Portsmouth in 1906, Charles Talbot received his education at Mundella School in Nottingham. His university education was at the Gregorian University in Rome, and he returned to England to teach philosophy and classics at Mount St Bernard Abbey, Charnwood Forest, in Leicester, from 1930 until 1946. From 1947 until 1954, he was a librarian at the Warburg Institute in London, and in 1954 he joined the Wellcome Institute for the History of Medicine in London as their medievalist, where he worked until his retirement.

Dr Talbot's The Anglo-Saxon missionaries in Germany (1954) helped to establish him as a major scholar in the field of medieval studies. This was followed by editions of the works of Bernard of Clairvaux (1957, with J. Leclercq and H. M. Rochais), and Ailred of Rievaulx (1971, with A. Hoste). He published the Life of Christina of Markyate in 1959. In 1965 he collaborated with E. A. Hammond to produce The medical practitioners in medieval England: a biographical register, which quickly became the standard reference tool in the field. This was followed in 1967 by Medicine in medieval England, a survey text. He lectured and taught widely in England, Canada, the United States, and elsewhere.

His approach to medieval medical history was governed by two very different influences on his formation as an historian. On the one hand, he reacted strongly against that dark, dismissive view of the European Middle Ages which refused to allow that any aspect of medieval thought or practice deserved the noble name of science. This attitude was most forcibly expressed in George Sarton's widely influential series of volumes, Introduction to the history of science (c. 1927-1948). On the other hand, his training had been in the rigours and subtleties of medieval philosophy and theology, disciplines which left him with an abiding doubt about the intellectual worth of medieval medical and scientific thought. There was more of George Sarton in Charles Talbot than he cared to admit or, perhaps, realized. In spite of his ambivalent views on medieval science, he was one of the first, competent medievalists in the post-war English-speaking world to treat medieval medicine seriously on the basis of a first-hand knowledge of its, mostly manuscript, texts.

An avid gardener and a keen rambler, Charles Talbot continued to be as active as possible even when slowed by a series of strokes toward the end of his life. Visitors to his home in southeast London could count on generous hospitality, a keen and sometimes dangerous wit, and a fervent love of the outdoors, which coloured nearly every conversation. Surrounded by books (more than twenty written by himself), Charles Talbot maintained a lively interest in the life of the mind and a delight in nature throughout his long and productive life. 